\title{
Campus Adaptations among First Generation and Non First- Generation Students
}

\author{
Dr. Vijayalakshmi N.S ${ }^{1^{*}}$, Dr. A.H Sequeira ${ }^{2}$ \\ 1, ${ }^{*}$ Faculty, Post graduate Department of Economics, University college mangalore, hampankatta, Mangalore - \\ 575001, karnataka \\ ${ }^{2}$ Professor \& Dean Faculty welfare, School of Management, National Institute of Technology Karnataka, \\ Surathkal-Mangalore 575025
}

*Corresponding Author: Dr. Vijayalakshmi N.S, Faculty, Post graduate Department of Economics, University college mangalore, hampankatta, Mangalore -575001, karnataka

\begin{abstract}
:
Objective: The study aims to empirically test the relationship between types of campus adaptations across first to fifth generation of engineering undergraduate B.Tech students pursuing a four year study at Indian Institute of Technology (IIT's) and National Institute of Technology (NIT's) in India.

Method: The Multivariate Analysis of Variance (Manova) test was run with SPSS vs. 21 to compare the student's campus adaptations of IIT's and NIT's by generation status of first generation $(n=956)$, second generation $(n=338)$, third generation $(n=103)$, fourth generation $(n=14)$ and fifth generation $(n=09)$. Multistage random sampling with $n=1420$ students were selected.

Result: In academic adaptation, second and third generation students had positive outcomes while first, fourth and fifth generation had negative outcomes. In social adaptation, first, third and fifth generation students had positive outcomes while second and fourth generation students had negative outcomes. In physical - psychological adaptation, the first, third and fourth generation students had positive outcomes while the second and fifth generation students had negative outcomes. In institutional adaptation second, third, fourth and fifth generation students had positive outcomes while first generation students had negative outcomes.

Conclusions: There are significant differences among student generation from first to fifth on different forms of campus adaptations. In short, campus adaptations do vary across generation status influencing student's experiences at university.
\end{abstract}

Keywords: Campus; Adaptation, First Generation, Non First Generation, Students Experiences and Student Satisfaction

\section{INTRODUCTION}

College students generational status impacts students adjustment to college (Hertel, 2002). It is observed that first generation students navigation in educational system differs from non first generation students (Kirshner, Saldivar, \& Tracy, 2011) impacting differed experiences among first generation college students at campuses (Spiegler \& Bednarek, 2013) resulting in diverse educational outcomes among first generation and non first generation students (Bodovski \& Benavot, 2006). The youth as generation (Naafs \& White, 2012) serving as first generation students of human resource provide motivation and aspiration for next generations (Rahim \& Azman, 2010) that best prepares millennial generation engineering students for complex challenges (Kahle \& Hansen, 2009) broadening participation in science and engineering of the next generation (Madsen \& Tessema, 2009).

First generation college students in engineering (Trenor, 2009) are usually driven to achieve (Rood, 2009) resulting the much needed intergenerational breakthrough of first generation college students in education (Gofen, 2009) who by far have remained underrepresented at university (Lam, Srivatsan, Doverspike, Vesalo, \& Mawasha, 2005). The type of education impacts enrolment of first births in the 
family - first generation (Martin-Garcia \& Baizan, 2006). Further college readiness and academic preparation for postsecondary education of first-generation urban college students (Reid \& III, 2008) define first generation Students (Lang, 2009). Hence special attention to the needs of first generation engineering college students in learning is warranted (Trenor \& Grant, 2009). This is supported by generation theory in higher education indicating that educational competencies between successive generations persist (Knight, 2009) with cultural capital theory impacting first generation student success as put forward by cultural capital theory(S. A. Dumais \& Ward, 2010).

The study seeks to analyse the relationship among student generation groups of first to fifth with the following research question and research objective:-

Research Questions: What makes campus adaptations of academic, social, physical - psychological and institutional attachment be unique across student generation of first to fifth?

Research Objectives: To examine existence of variance among campus adaptations of academic, social , physical psychological and institutional across student generation of first to fifth.

\section{CAMPUS AdAPTATIONS}

\subsection{Academic Adaptation}

First generation students academic transition in higher education (Inkelas et al., 2007) impacts student engagement by generation status (Gibson \& Slate, 2010) evident in intellectual development transformation observed in first and second generation students (Pike \& Kuh, 2005) that sharpens generic skills competency development among undergraduate students (Choi \& Rhee, 2014). It is observed that non first generation students have higher levels of academic involvement positively resulting in better academic performance than first generation students (Grayson, 1997) reflecting on the fact that educationally purposeful activity supports academic performance of first generation college students (Carr, Jackson, \& Murphy, 2014). Further with impressive learning on the go with generation Y students (Blashki, Nichol, Jia, \& Prompramote, 2007) motivation and integration of first generation college students impacts their academic performance (Próspero \& Vohra-Gupta, 2007) contributing to academic achievement (Trevino \& DeFreitas, 2014) that fosters educational attainment especially of first generation ethnic students of race (Próspero \& Vohra-Gupta, 2007). This is backed up by the current scenario of self regulated learning - the online learning revealing that first generation students report significantly lower levels of self-regulation for online learning than second generation students(P. E. Williams \& Hellman, 2004) impacting class attendance that varied by student of race of first and second generation students (Keller \& Tillman, 2008). Further with academic dishonesty also differing by generation status (E.Wotring \& Bol, 2011) creating crossgenerational co-learning opportunities through inquiry-based curricula (Théroux, 2009)could better the grades often differing among first generation and continuing generation (Aspelmeier, Love, McGill, Elliott, \& Pierce, 2012) which in long run replicates as barriers to career plans among engineering students of first generation (Fernandez, Trenor, Zerda, \& Cortes, 2008).

With regard to academic disciplines, first generation undergraduates students experiences at college differs at first year (Padgett, Johnson, \& Pascarella, 2012) and across academic disciplines (Peguero, Shekarkhar, Popp, \& Koo, 2015) especially among engineering academic disciplines (Hicks \& Prairie, 2014). This may be due to lack of proper guidance among first generation students on prominence of academic disciplines compared to continuing generation students (Trenor, 2009) impacting students persistence in engineering academic major (Virnoche \& Eschenbach, 2010). It could also have the sibling effect, where sibling educational choices impacts educational choices of the next sibling towards a particular academic discipline (Meurs, Puhani, \& Von Haaren-Giebel, 2016). The extended academic arena of student-faculty interaction also vary by first generation status of students (Kim \& Sax, 2009) as first generation traditional college students understanding of faculty expectations (Collier \& Morgan, 2008) and undergraduate expectations and preferences for instructors vary (Trammell \& Aldrich, 2016) impacting college success of first generation students (McKay \& Estrella, 2008). This acts as a paranoid with undergraduate college students especially of minority race who differ by gender and generation status on their views of effectiveness of faculty (Schulte, Slate, \& Onwuegbuzie, 2011). Never the less, soft skills could gear up the first generation teacher students interaction (M.S.Thirumalai, 2014) that positively facilitates academic and social transition of first generation students in academic arena. Thus college academic activities differ in levels among first generation and non first generation engineering students(Hicks \& Prairie, 2014) influencing 
academic achievement to vary by generation status (Duong, Badaly, Liu, Schwartz, \& McCarty, 2016) and educational achievements to vary among first and subsequent generation in education (Pandey, 2015).

\subsection{Social Adaptation}

Socialisation experiences varied by generation of students (Shields, 2002). First generation students social transition in higher education (Inkelas et al., 2007) reflect that the invisible barriers are real for first generation college students (Gardner \& Holley, 2011) indicating that the invisible hand of social capital impacts first generation college students in engineering (Martin, 2015) with first generation college students access to engineering social capital aiming towards developing a richer understanding of the same (Pfirman, Miller, Alvarez, \& Martin, 2014). Social capital impacts academic motivation among first generation college students (Moschetti \& Hudley, 2015) with social construction of social identity as a distinct social class among first generation students (Wildhagen, 2015) differing widely from first and non first generation students (Finch, 2016). However off the beat, there is a social capital deficit of first generation college students in engineering (Martin, Miller, \& Simmons, 2014). Hence first generation students need to cultivate a voice to seek full academic citizenship in multicultural learning communities (Jehangir, 2009). Further its noted that first generation students are significantly less likely to pursue an advanced degree in higher education and advance in pipeline (Carlton, 2015) with first generation female college students facing severe problems of transition and adjustment at college after transition in first year (A. Nuñez, 2005) impacting their academic success by gender and race factor alone. (Amelink, 2005). To this Special support systems need to be in place to enable transition of first generation women engineering students into four year program institutions (Fletcher, Newell, Anderson-Rowland, \& Newton, 2001). Counter spaces and connections formed with daily interactions on the go at campus impact college transition among first generation college students of race(A.-M. Nuñez, 2011) with apprehensions on communications persisting (Francis \& Miller, 2007) hindering the perceptions of lack of sense of community identity among first generation students (Orbe, 2004).

The social class has an impact on academic performance of first generation students whose performance avoidance goals were higher than second generation students (Mickaël Jury, Smeding, Court, \& Darnon, 2015) with successful support for diverse students differs among first generation social and ethnic minority students (Ecklund, 2013). It thus goes without saying that race and class impacts first generation college students experiences (Stuber, 2011) and that minority first generation college students experience (McGonagle et al., 2014) differ vastly. This could impact the identity transformation in first generation students of race and women (Wentworth \& Peterson, 2001) also adversely impacting their academic performance by age too (Wilkins, 2014). Students of minority race thus by far have remained underrepresented in engineering education (Lam et al., 2005). This can be counterfeited by faculty, counsellors, university officials, parents by mentoring students impacting first generation college students of race (Vega \& Moore, 2012). Mentoring first generation college students leads to academic success, valuing school, increasing future potential, decision making and support and encouragement.(Wang, 2012). Undoubtedly communication events via mentoring shape first generation students pedagogical and inter personal relationships with teachers (Wang, 2012). From the perspective of social capital lens - social media helps first generation high school students college aspirations (Wohn, Ellison, Khan, Fewins-Bliss, \& Gray, 2013) where generation Y students use facebook for communication with faculty(Pinzaru \& Mitan, 2013).

The social support system via family needs a special introspection where family influence impacts underrepresented first generation low income college students persistence towards graduation (Tate et al., 2015). The family context is important to consider in the adjustment and success of firstgeneration college students(Covarrubias et al., 2014) as among first generation students non cognitive factors have a greater contribution to students success(Peterson, 2016) with family support vehemently impacting first generation college students (Boehmer, 2014). Parents do influence educational aspirations among first generation students towards pursuing tertiary education (Rahim \& Azman, 2010) with generational difference in gender attitudes between parents helping out a cold play (Cichy, Lefkowitz, \& Fingerman, 2007). Never the less, an extra mile on social support , the full on follow back through peers impacts better college adjustment especially among minority students of race (Dennis, Phinney, \& Chuateco, 2005) (Burgos-Cienfuegos, Vasquez-Salgado, Ruedas-Gracia, \& Greenfield, 2015). Not much lying far behind the economic perspective among first generation 
students reflect financial problems have a greater impact on first generation students (Hailu \& $\mathrm{Ku}$, 2014) with first year first generation students academic success varying by financial need (Amelink, 2005) . It is often observed that first generation students are more sensitive to financial aid and averse to student loans than their peers (Somers, Woodhouse, \& Cofer, 2004). This is fuelled by lower income of the family impacting educational attainment in first generation college students (Erin \& Nadine, 2014). On the whole, first generation low income students are underrepresented in higher education (Mawasha, 2008) and families economic condition impacts inequality persistence across generations (Franzini \& Raitano, 2009). Such financial crunches have resulted in first generation students showing benevolence towards distance education enrolment (Pontes \& Pontes, 2012).

The social perspective seems incomplete without the cultural introspective where language difficulties are challenges first generation students witness at campuses (Hailu \& $\mathrm{Ku}, 2014$ ) especially among first year first generation students academic success where language holds the key at distant place (Amelink, 2005). The association of students with cultural norms, where following an independent cultural norms results in negative emotions with cultural mismatch among first generation college students (Stephens, Townsend, Markus, \& Phillips, 2012). Culture acts as a source of support among students of minority race among first and second generation college students (Kouyoumdjian, Guzman, Garcia, \& Talavera-Bustillos, 2015) and second generation students quality of integration process in institutions depends on heritage and culture with identity and group dimensions (Damigella, Damigella, Licciardello, \& Anello, 2016). The lack of culture awareness are next best challenges first generation students face (Hailu \& Ku, 2014). However the cultural capital impacts academic achievement of first generation students (Paul Grayson, 2011) and the cultural shifts impacted positive self evaluation by generations (Twenge, Campbell, \& Gentile, 2012). Lastly the touch of spirituality combats loneliness and homelessness which is higher among first generation students than non first generation students (Ferrari, Drexler, \& Skarr, 2015). In Brief, socialisation of first generation students of engineering impact nurturing next generation students in academic discipline (Szelenyi, 2013).

\subsection{Physical - Psychological Adaptation}

Psychology differs among generations (Lub, Bal, Blomme, \& Schalk, 2016) with family achievement guilt impacting mental well-being of college students (Covarrubias et al., 2014). Social cognitive career theory states that self efficacy outcome expectations, barriers, and goals can help with career and academic decision-making meets the needs of first generation college students (Gibbons \& Shoffner, 2004) resulting in lower self efficacy of first generation students (Gibbons \& Borders, 2010) adversely impacting their academic performance and college adjustment(Ramos-Sánchez \& Nichols, 2007). Self efficacy also impacts academic success among ethnically diverse students of minority race of first generation (Majer, 2009) where social academic self efficacy differs among first and non first generation students of higher education (Finch, 2016). Further self efficacy, coping efficacy impacts underrepresented first generation low income college students persistence towards graduation(Tate et al., 2015).

Students at campuses face lack of social support influencing depression impacting life satisfaction of first generation college students(Jenkins, Belanger, Connally, Boals, \& Durõn, 2013) . First generation students also witness higher bullying, violence and suicidal behaviours than third generation (Pottie, Dahal, Georgiades, Premji, \& Hassan, 2014) impacting self-esteem and locus of control that differs among first generation and continuing generation (Aspelmeier et al., 2012).This builds up the stress which varies by generation of students where second generation is able to counter balance stress effectively (Shields, 2002). Hence stressors and supports differ among first generation and non first generation students(S. A. Dumais, Rizzuto, Cleary, \& Dowden, 2013). To this the great source of help could arrive at campus is through counselling. Counselling impacts retention of first generation college students (Pham \& Keenan, 2011) by enhancing the sense of belonging (Stebleton, Soria, Huesman, \& Torres, 2014) especially facilitating first generation female college students transition into higher education environment which is challenged with process of forming self identity (O'Shea, 2014). Counselling thereby gives a sense of direction to first generation students who are often stranded by time constraints and inadequate guidance (Hailu \& Ku, 2014) Thus behavioural typology of first-time first generation students (Bahr, 2010) reflect that social cognitive factors impact academic and student life satisfaction varies among first and non first generation students (Garriott, Hudyma, Keene, \& Santiago, 2015). 


\subsection{Institutional Adaptation}

Institutional culture impacts first generation college students (Erin \& Nadine, 2014) with institutional mission impacting generic skills competency development among undergraduate students(Choi \& Rhee, 2014) . If the universities focus on independence, it undermines academic performance of first generation students (Stephens, Fryberg, Markus, Johnson, \& Covarrubias, 2012) as its never bereaved of the fact that its institutional choice of students that draws the margin line of difference impacting first generation students underperformance at institutions (Micka $\tilde{A} \ll 1$ Jury, Smeding, \& Darnon, 2015). The persistence levels in higher education differs from first generation to continuing generation(Martin Lohfink \& Paulsen, 2005) with persistence factors of first generation impacting first year students persistence (Stieha, 2010). The early experiences and integration in the persistence of first-generation college students in engineering and non engineering academic majors (Dika \& D'Amico, 2016) needs an on look as the supposedly attrition factors could hard hit first generation more (Ishitani, 2003) resulting in lack of belongingness in lower academic achievement school dropouts, and less institutional involvement among first generation students (S. M. Williams \& Ferrari, 2015). Hence retention of first generation students need to be focused with special attention(Watt, Johnston, Huerta, Mendiola, \& Alkan, 2008) on for their success (Hawthorne \& Young, 2010) where first generation students often are left demining with lower grades (D'Amico \& Dika, 2013). This can be tethered further by positive academic engagement among first generation students resulting in successful retention over the academic years (Soria \& Stebleton, 2012) with concerns of retention of first generation minority students in post secondary institutions still brewing over the matter for long (Harrell \& Forney, 2003). The less spoken off living learning community positively impacts academic performance of first generation college students(Flynn, Everett, \& Whittinghill, 2015) with residence halls greatly influencing the academic and social transition of first generation students (Inkelas et al., 2007). Further it leaves one jaws down where one notices that first generation or non native english speakers has high rate of degree completion(Schuetz, 2014).

The study perpetuates the following research hypothesis:-

$\mathrm{H}_{1:}$ Campus adaptations of academic, social, physical - psychological and institutional environments does not vary among undergraduate students by their generation status

$\mathrm{H}_{1 \mathrm{a}}$ : There is a significant difference among undergraduate students across first to generations in campus adaptations of academic, social, physical - psychological and institutional adaptations.

\section{METHODS}

\subsection{Participant}

The reference population were undergraduate 4 year B.tech students enrolled on a regular study mode at IIT's and NIT's. A total of 1460 students participated with 1420 of valid responses for an overall 97.26 percent participation rate after deducting the questionnaire that contained empty answers. Data was collected for 20 weeks across institutions of IIT's and NIT's. Of the 1420 undergraduate respondents, $67.32 \%$ were first generation students, $23.80 \%$ were second generation students, $7.25 \%$ were third generation students, $0.98 \%$ were fourth generation students and $0.63 \%$ were the fifth generation students.

\subsection{Sampling}

Probability sampling technique followed by cluster sampling in identification of institutes of IIT's and NIT's was adopted. This is followed up with stratified sampling in sample choice of undergraduate students' population and simple random in collecting data from the chosen student population stated above.

\subsection{Instrument and Procedure}

The survey was conducted using a structured online questionnaire with reference to student's campus and non campus email accounts. At all times, the students were informed of the anonymous, confidential, and voluntary nature of their participation and any doubts that arose were clarified.

\subsection{Measures}

All the 21 items in the questionnaire were measured with rating on a five point likert scale ranging from " $1=$ strongly disagree" to " $5=$ strongly Agree". Reliability and validity of the questionnaire was tested 


\section{Data ANALYSIS}

Multivariate analyses of variance (MANOVA) were conducted to asses' student's generation status group differences in campus adaptation. This was followed by discriminant analysis to determine the nature of effect of campus adaptations by each generation status group. There are several assumptions behind a MANOVA, including multivariate normality, linearity of relationships, low influence of univariate and multivariate outliers, homogeneity of variance- covariance matrices and an absence of multicollinearity. Each assumption was tested, and no serious violations were noted.

Table1. Pearson Correlation

\begin{tabular}{|l|c|c|c|c|c|c|}
\hline \multicolumn{1}{|c|}{ Campus Adaptation } & $\mathbf{1}$ & $\mathbf{2}$ & $\mathbf{3}$ & $\mathbf{4}$ & \multicolumn{1}{|c|}{ M } & SD \\
\hline 1.Academic Adaptation & 1.00 & & & & 2.60 & 0.702 \\
\hline 2.Social Adaptation & .578 & 1.00 & & & 2.72 & 0.755 \\
\hline 3.Physical - Psychological Adaptation & .524 & .579 & 1.00 & & 2.28 & 0.771 \\
\hline 4.Institutional Adaptation & .575 & .616 & .790 & 1.00 & 2.14 & 0.784 \\
\hline
\end{tabular}

Note: $n=1420$.Correlations greater than 0.05 are statistically significant $(p<0.5)$

Pearson product moment correlation analyses that examined the relationship between campus adaptations revealed correlations greater than 0.05 , hence statistically significant

Table2. Distribution of difference in dimensions of campus adaptations

\begin{tabular}{|c|c|c|c|c|c|c|c|c|}
\hline \multirow[t]{2}{*}{ Generation Status of students } & \multicolumn{2}{|c|}{ Academic } & \multicolumn{2}{|c|}{ Social } & \multicolumn{2}{|c|}{$\begin{array}{c}\text { Physical - } \\
\text { Psychological }\end{array}$} & \multicolumn{2}{|c|}{ Institutional } \\
\hline & Mean & Std. Dev & Mean & Std. Dev & Mean & Std. Dev & Mean & Std. Dev \\
\hline First generation $(n=956)$ & 2.61 & 0.712 & 2.72 & 0.754 & 2.26 & 0.768 & 2.13 & 0.782 \\
\hline Second generation $(\mathrm{n}=338)$ & 2.54 & 0.671 & 2.70 & 0.732 & 2.31 & 0.752 & 2.14 & 0.755 \\
\hline Third generation $(\mathrm{n}=103)$ & 2.67 & 0.708 & 2.72 & 0.807 & 2.48 & 0.773 & 2.26 & 0.871 \\
\hline Fourth generation $(\mathrm{n}=14)$ & 2.50 & 0.616 & 2.88 & 0.879 & 2.10 & 1.019 & 1.91 & 0.709 \\
\hline Fifth generation $(\mathrm{n}=09)$ & 2.94 & 0.790 & 2.86 & 1.00 & 2.15 & 1.156 & 2.33 & 1.122 \\
\hline Total $(n=1420)$ & 2.60 & 0.702 & 2.72 & 0.755 & 2.28 & 0.771 & 2.14 & 0.784 \\
\hline
\end{tabular}

The mean in the descriptive statistics indicate that among undergraduate B.Tech students, students enjoyed high level of social adaptation from first to fourth generation with first generation $(\mathrm{M}=2.72$, $\mathrm{SD}=0.754)$, second generation $(\mathrm{M}=2.70, \mathrm{SD}=0.732)$, third generation $(\mathrm{M}=2.72, \mathrm{SD}=0.807)$ fourth generation $(\mathrm{M}=2.88, \mathrm{SD}=0.879)$. it is observed that the fifth generation alone had high academic adaptation $(\mathrm{M}=2.94, \mathrm{SD}=0.790)$

However students from first to fourth generation had lower level of institutional adaptation with first generation $(\mathrm{M}=2.13, \mathrm{SD}=0.782)$, second generation $(\mathrm{M}=2.14, \mathrm{SD}=0.755)$ third generation $(\mathrm{M}=$ $2.26, \mathrm{SD}=0.871)$ fourth generation $(\mathrm{M}=1.91, \mathrm{SD}=0.709)$ It is observed that fifth generation students had low level of physical - psychological $(\mathrm{M}=2.15, \mathrm{SD}=1.156)$ adaptation.

Further within Academic Adaptation, fifth generation had high level of impact on adaptation $(\mathrm{M}=$ $2.94, \mathrm{SD}=0.790)$ and second generation had low level of adaptation $(\mathrm{M}=2.54, \mathrm{SD}=0.671)$

In Social Adaptation, fourth generation had high level of impact on adaptation $(\mathrm{M}=2.88, \mathrm{SD}=0.879)$ and second generation impacted in low level of adaptation $(\mathrm{M}=2.70, \mathrm{SD}=0.732)$

In Physical - Psychological adaptation, third generation students had high impact on level of adaptation $(\mathrm{M}=2.48, \mathrm{SD}=0.773)$ and fourth generation impacted in low level of adaptation $(\mathrm{M}=$ $2.10, \mathrm{SD}=1.019)$

In Institutional adaptation, fifth generation had high impact on students level of adaptation $(M=2.33$, $\mathrm{SD}=1.122)$ and fourth generation students impacted on students low level of adaptation $(\mathrm{M}=1.91$, $\mathrm{SD}=0.709)$

Overall, across campus adaptations and fathers educational level groups, students had high level of social adaptation $(\mathrm{M}=2.72, \mathrm{SD}=0.755)$ and low level of Institutional adaptation $(\mathrm{M}=2.14, \mathrm{SD}$ $=0.784)$. However within generations, fifth generation had high level of academic adaptation $(\mathrm{M}=$ $2.94, \mathrm{SD}=0.790)$ and fourth generation had low level of institutional adaptation $(\mathrm{M}=1.91, \mathrm{SD}=$ $1.122)$

The Box's $M$ value of 47.430 indicates test of assumption of equality of covariance matrices are roughly equal as assumed with $p=0.333(\mathrm{p}>0.001)$. 
Using Manova test statistic of Pillai's Trace, there was a significant effect of age on students Academic, Social, Physical - Psychological and Institutional campus adaptations $(\mathrm{V}=0.020, F$ $(16,5660)=1.796$ and $p=0.026) *(p<0.05)$.

Using Manova test statistic of Wilks Lambda, there was a significant effect of age on students Academic, Social, Physical - Psychological and Institutional campus adaptations $(\Lambda=0.980, F$ $(16,4314)=1.798$ and $p=0.026) *(p<0.05)$.

Using Manova test statistic of Hotelling's trace, there was a significant effect of age on students campus adaptations of Academic, Social, Physical - Psychological and Institutional ( $\mathrm{T}=0.020, F$ $(16,5642)=1.799$ and $p=0.026) *(p<0.05)$.

Using Manova test statistic of Roy's largest root, there was a significant effect of age on students campus adaptations of Academic, Social, Physical - Psychological and Institutional $(\Theta=0.013, F$ $(4,1415)=4.498$ and $p=0.001) *(p<0.05)$.

The univariate test statistic with levenes test of equality of variances for each of the dependent variable is non significant $i, e p>0.05$ with academic adaptation of 0.361 , social adaptation of 0.682 , physical - psychological adaptation of 0.717 and institutional adaptation of 0.206 enabling the assumptions of homogeneity of variance being met.

However separate univariate analysis or anova on the outcome with F $(4,1415)$ for Academic, social and institutional adaptation revealed a non significant effect with $F$ value (1.437) (0.272) (1.027) and $\mathrm{p}$ value (0.219) (0.896) (0.392) while it revealed a significant effect of physical - psychological adaptation with $\mathrm{F}$ value of (1.027) and $\mathrm{p}$ value greater than $0.05(0.058)$

Further the between - subjects SSCP matrix indicates that the sum of squares for the error SSCP matrix are substantially bigger than in the model (or generation) SSCP matrix, whereas absolute values of cross products are fairly similar. This pattern of relationship indicates that the relationship between dependent variables is significant than individual dependent variables themselevs. Thus to determine the nature of effect of generation status among dependent variables Manova is followed with discriminant analysis

The first discriminant function explained $62.3 \%$ of the variance with canonical $\mathrm{R}^{2}=0.013$; the second discriminant function explained $31.5 \%$ of the variance with canonical $\mathrm{R}^{2}=0.006$; the third discriminant function explained $5.1 \%$ of the variance with canonical $\mathrm{R}^{2}=0.001$; the fourth discriminant function explained $1.1 \%$ of the variance with canonical $\mathrm{R}^{2}=0.000$ indicates that the variance in the canonical derived dependnant variable was associated for generation status

In combination these discriminant functions significantly discriminated the generation groups. The first discriminant function significantly differentiated the student groups of generation, with the first function $\Lambda=0.980, \mathrm{x}^{2}(16) 28.724, \mathrm{p}=0.026(p<0.05)$

However second discriminant function $\Lambda=0.992, \mathrm{x}^{2}(9) 10.850, \mathrm{p}=0.286(p>0.05)$. the third discriminant function $\Lambda=0.999, \mathrm{x}^{2}$ (4) $1.800, \mathrm{p}=0.773(p>0.05)$ and the fourth discriminate function $\Lambda=0.999, \mathrm{x}^{2}(1) 0.330, \mathrm{p}=0.566(p>0.05)$. indicates the non significant effect of discriminant functions

The correlations between outcomes and the discriminant functions revealed that Physical Psychological adaptation loaded highly on first function $(\mathrm{r}=0.668)$ indicating it contributed more to the generation group separation (Bragman, 1970) than the relatively fair high loading in positive relationship with second function $(r=0.295)$ third function $(r=0.394)$ and fourth function $(r=0.558)$;

Academic adaptation loaded highly on second function $(r=0.737)$ indicating it contributed more to the age group separation than the relatively high loading in positive relationship with third function $(\mathrm{r}$ $=0.617)$ and fourth function $(\mathrm{r}=0.253)$ negated by negative relationship in the first function $(\mathrm{r}=-$ $0.115)$;

Social adaptation loaded highly on fourth function with $(\mathrm{r}=0.805)$ indicating it contributed more to the generation group separation than the relatively fair high loading in the second function $(r=0.004)$ third function $(r=0.574)$ with negative relationship in first function $(r=-0.147)$

Institutional adaptation loaded highly on fourth function with $(r=0.801)$ indicating it contributed more to the generation group separation than the relatively fair high loading in positive relationship with second function $(r=0.525)$ third function $(r=0.380)$ and first function $(r=0.209)$ 


\subsection{Findings}

The first generation students had positive outcomes on social (0.015) and Physical - Psychological adaptations (0.001) with negative outcome on academic (-0.051) and institutional adaptation (-0.008)

The second generation students had positive outcomes on academic (0.086) and institutional adaptation (0.014) with negative outcomes on social (-0.073) and Physical - Psychological adaptation $(-0.031)$

The third generation students had positive outcomes on academic (0.283), social (0.122), Physical Psychological (0.064) and Instiuttional (0.006) adaptation.

The fourth generation students had positive outcomes on Physical - Psychological (0.228) and institutional (0.045) adaptation with negative outcome on academic $(-0.334)$ and social $(-0.459)$ adaptation.

The fifth generation students had positive outcomes on social (0.535) and institutional (0.139) adaptation with negative outcomes on academic (-0.596) and Physical - Psychological (-0.023) adaptation

In brief the alternate hypothesis $\left(\mathrm{H}_{1}\right)$ is accepted and the null hypothesis $\left(\mathrm{H}_{0}\right)$ is rejected at $\mathrm{p}<0.05$.

In short, campus adaptations vary across first to fifth generation engineering undergraduate students.

\section{CONCLUSION}

College Adjustment differs among first generation and continuing generation (Aspelmeier, Love, McGill, Elliott, \& Pierce, 2012) where being the first in family or first generation results in poorer academic outcomes (Southgate, Douglas, Scevak, Macqueen, \& Rubin, 2014) . In brief higher engineering education has a differential impact on across generations at campus institutions of NIT's and IIT's in India.

\section{IMPLICATIONS OF THE STUDY}

The influx of students in post economic reform period of 1990 into engineering education had the populated strength of those students who were first to the arena of higher education; the first to its nature of getting accustomed to institutions and its campuses environment. The experiences of such students lay stranded amidst the hue and cry of curriculum and grades alone. The personification of campus experiences via its types of adaptations displays its vividness witnessed among first and non first generation students. This work could seek an extension on campus experiences of post graduate and research students, which has remain undisclosed for long.

\section{REFERENCES}

[1] Amelink, C. (2005). Predicting Academic Success Among First-Year, First Generation Students. Retrieved from http://faculty.ksu.edu.sa/hisham/Documents/MedicalEducation/English/Admission/2.pdf

[2] Aspelmeier, J. E., Love, M. M., McGill, L. A., Elliott, A. N., \& Pierce, T. W. (2012). Self-Esteem, Locus of Control, College Adjustment, and GPA Among First- and Continuing-Generation Students: A Moderator Model of Generational Status. Research in Higher Education, 53(7), 755-781. http://doi.org/10.1007/s11162-011-9252-1

[3] Bahr, P. R. (2010). The Bird's Eye View of Community Colleges: A Behavioral Typology of First-Time Students Based on Cluster Analytic Classification. Research in Higher Education, 51(8), 724-749. http://doi.org/10.1007/s11162-010-9180-5

[4] Birani, A., \& Lehmann, W. (2013). Ethnicity as social capital: an examination of first-generation, ethnicminority students at a Canadian university. International Studies in SociologyofEducation, 23(4), 281-297. http://doi.org/10.1080/09620214.2013.822715

[5] Blashki, K., Nichol, S., Jia, D., \& Prompramote, S. (2007). "The future is old": immersive learning with generation Y engineering students. European Journal of Engineering Education, 32(4), 409-420. http://doi.org/10.1080/03043790701334228

[6] Bodovski, K., \& Benavot, A. (2006). Unequal Educational Outcomes among First-Generation Immigrants: the case of youth from the former Soviet Union in Israel. Research in Comparativeand International Education, 1(3), 253. http://doi.org/10.2304/rcie.2006.1.3.253

[7] Boehmer, J. K. (2014). First in My Family: Perceived Family Support and Impact on First-Generation College Students within a Community College Cohort Program Setting. 
[8] Burgos-Cienfuegos, R., Vasquez-Salgado, Y., Ruedas-Gracia, N., \& Greenfield, P. M. (2015). Disparate Cultural Values and Modes of Conflict Resolution in Peer Relations: The Experience of Latino FirstGeneration College Students. Hispanic Journal of Behavioral Sciences, 37(3), 365-397. http://doi.org/10.1177/0739986315591343

[9] Carlton, M. T. (2015). First Generation Students and Post-Undergraduate Aspirations. SAGE Open, 5(4), 2158244015618433-. http://doi.org/10.1177/2158244015618433

[10] Carr, J. M., Jackson, D. D., \& Murphy, M. K. (2014). Using Educationally Purposeful Activities to Support First-Generation College Students in Chemistry, (February 2016).

[11] Choi, B. K., \& Rhee, B. S. (2014). The influences of student engagement, institutional mission, and cooperative learning climate on the generic competency development of Korean undergraduate students. Higher Education, 67(1), 1-18. http://doi.org/10.1007/s10734-013-9637-5

[12] Cichy, K. E., Lefkowitz, E. S., \& Fingerman, K. L. (2007). Generational differences in gender attitudes between parents and grown offspring. Sex Roles, 57(11-12), 825-836. http://doi.org/10.1007/s11199-007-9314-1

[13] Collier, P. J., \& Morgan, D. L. (2008). “is that paper really due today?”: Differences in first-generation and traditional college students' understandings of faculty expectations. Higher Education, 55(4), 425-446. http://doi.org/10.1007/s10734-007-9065-5

[14] Covarrubias, R., Romero, A., \& Trivelli, M. (2014). Family Achievement Guilt and Mental Well-being of College Students. Journal of Child and Family Studies, 24(7), 2031-2037. http://doi.org/10.1007/s10826014-0003-8

[15] D’Amico, M. M., \& Dika, S. L. (2013). Using data known at the time of admission to predict firstgeneration college student success. Journal of College Student Retention: Research, Theory and Practice, 15(2), 173-192. http://doi.org/10.2190/CS.15.2.c

[16] Damigella, D., Damigella, D., Licciardello, O., \& Anello, S. (2016). Second generation , integration processes and cultural affiliations . A study with a group of students. In Proc. of the Third Intl. Conf. Advances in Social Science, Economics and Management Study- SEM 2015 (Vol. 55, pp. 20-24). Springer US. http://doi.org/10.15224/978-1-63248-063-7-42

[17] Dennis, J. M., Phinney, J. S., \& Chuateco, L. I. (2005). The Role of Motivation, Parental Support, and Peer Support in the Academic Success of Ethnic Minority First-Generation College Students. Journal of College Student Development, 46(3), 223-236. http://doi.org/10.1353/csd.2005.0023

[18] Dika, S. L., \& D’Amico, M. M. (2016). Early experiences and integration in the persistence of firstgeneration college students in STEM and non-STEM majors. Journal of Research in Science Teaching, 53(3), 368-383. http://doi.org/10.1002/tea.21301

[19] Dumais, S. a., Rizzuto, T. E., Cleary, J., \& Dowden, L. (2013). Stressors and Supports for Adult Online Learners: Comparing First- and Continuing-Generation College Students. American Journal of Distance Education, 27(2), 100-110. http://doi.org/10.1080/08923647.2013.783265

[20] Dumais, S. A., \& Ward, A. (2010). Cultural capital and first-generation college success. Poetics, 38(3), 245-265. http://doi.org/10.1016/j.poetic.2009.11.011

[21] Duong, M. T., Badaly, D., Liu, F. F., Schwartz, D., \& McCarty, C. A. (2016). Generational Differences in Academic Achievement Among Immigrant Youths: A Meta-Analytic Review. Review of Educational Research, 86(1), 3-41. http://doi.org/10.3102/0034654315577680

[22] E.Wotring, K., \& Bol, L. (2011). Generational Differences among Community College Students in their Evaluation of Academic Cheating. Community College Journal of Research \& Practice, 35(9), 724-735. http://doi.org/10.1080/10668920802095910

[23] Ecklund, K. (2013). First-Generation Social and Ethnic Minority Students in Christian Universities: Student Recommendations for Successful Support of Diverse Students. Christian Higher Education, 12(3), 159-180. http://doi.org/10.1080/15363759.2011.598377

[24] Erin, D., \& Nadine, D. (2014). eScholarship provides open access, scholarly publishing services to the University of California and delivers a dynamic research platform to scholars worldwide. InterActions: UCLA Journal of Education and Information Studies, 4(3), 1-18. http://doi.org/10.5811/westjem. 2011.5.6700

[25] Fernandez, M. J., Trenor, J. M., Zerda, K. S., \& Cortes, C. (2008). First generation college students in engineering: A qualitative investigation of barriers to academic plans. In Proceedings - Frontiers in Education Conference, FIE (pp. 1-5). http://doi.org/10.1109/FIE.2008.4720256

[26] Ferrari, J. R., Drexler, T., \& Skarr, J. (2015). Finding a spiritual home: A pilot study on the effects of a spirituality retreat and loneliness among urban homeless adults. Psychology, 6(3), 210-216. http://doi.org/10.4236/psych.2015.63020

[27] Finch, A. R. (2016). Social Identity and Social / Academic Self-Efficacy Among First-Generation ( Versus Non-First- Generation ) College Students, (February). 
[28] Fletcher, S. L., Newell, D. C., Anderson-Rowland, M. R., \& Newton, L. D. (2001). The Women in Applied Science and Engineering Summer Bridge Program:Ineasing the transition for first-time female engineering students. In 31st Annual Frontiers in Education Conference. Impact on Engineering and Science Education. Conference Proceedings (Cat. No.01CH37193) (Vol. 3, pp. 5-9). http://doi.org/10. 1109/ FIE.2001.964001

[29] Flynn, M. a., Everett, J. W., \& Whittinghill, D. (2015). The impact of a living learning community on firstyear engineering students. European Journal of Engineering Education, 3797(July), 1-11. http://doi.org/10.1080/03043797.2015.1059408

[30] Francis, T. a., \& Miller, M. T. (2007). Communication Apprehension: Levels of First-Generation College Students at 2-Year Institutions. Community College Journal of Research and Practice, 32(1), 38-55. http://doi.org/10.1080/10668920701746688

[31] Franzini, M., \& Raitano, M. (2009). Persistence of inequality in Europe: the role of family economic conditions. International Review of Applied Economics, 23(3), 345-366. http://doi.org/10.1080/0269 2170902811777

[32] Gardner, S. K., \& Holley, K. a. (2011). "Those invisible barriers are real”: The Progression of FirstGeneration Students Through Doctoral Education. Equity \& Excellence in Education, 44(1), 77-92. http://doi.org/10.1080/10665684.2011.529791

[33] Garriott, P. O., Hudyma, A., Keene, C., \& Santiago, D. (2015). 'Social cognitive predictors of first- and non-first-generation college students' academic and life satisfaction. Journal of Counseling Psychology, 62(2), 253-263. http://doi.org/10.1037/cou0000066

[34] Gibbons, M. M., \& Borders, L. D. (2010). Prospective First-Generation College Students: A SocialCognitive Perspective. The Career Development Quarterly, 58(3), 194-208. http://doi.org/10.1002/j.21610045.2010.tb00186.x

[35] Gibbons, M. M., \& Shoffner, M. F. (2004). Prospective First-Generation College Students : Meeting Their. ASCA, 8(1), 91-97.

[36] Gibson, A. M., \& Slate, J. R. (2010). Student Engagement at Two-Year Institutions: Age and Generational Status Differences. Community College Journal of Research and Practice, 34(5), 371-385. http://doi.org/10.1080/10668920802466384

[37] Gofen, A. (2009). Family capital: How first-generation higher education students break the intergenerational cycle. Family Relations, 58(1), 104-120. http://doi.org/10.1111/j.17413729.2008.00538.x

[38] Grayson, J. P. (1997). First-Generation Students in a Canadian University. Research in Higher Education, 38(6), 659-676. http://doi.org/10.1023/A:1024955719648

[39] Hailu, T. E., \& Ku, H. (2014). The Adaptation of the Horn of Africa Immigrant Students in Higher Education. The Qualitative Report, 19(55), 1-19. Retrieved from http://www.nova.edu/ssss/QR/QR19/ hailu55.pdf

[40] Harrell, P. E., \& Forney, W. S. (2003). Ready or Not, Here We Come: Retaining Hispanic and FirstGeneration Students in Postsecondary Education. Community College Journal of Research and Practice, 27(2), 147-156. http://doi.org/10.1080/713838112

[41] Hawthorne, M., \& Young, A. (2010). First-Generation Transfer Students' Perceptions: Implications for Retention and Success. THE JOURNAL OF COLLEGE ORIENTATION AND TRANSITION, 17(2), 29-39. Retrieved from http://www.researchgate.net/publication/259601674_First_Generation_Transfer _Students'_Perceptions_Implications_for_Retention_and_Success_(2010)/file/9c96052cdab80afb2d.pdf

[42] Hertel, J. B. (2002). College Student Generational Status: Similarities, Differences, and Factors in College Adjustment. The Psychological Record, 52, 3-18. http://doi.org/Article

[43] Hicks, T., \& Prairie, J. W. (2014). Firs-generation College Students and Non-First- generation College Students Enrolled in a Science, Technology, Engineering, and Mathematics ( STEM ) Discipline: A Comparison of their ... In international conferecne on urban education (pp. 291-297).

[44] Inkelas, K. K., Daver, Z. E., Vogt, K. E., \& Leonard, J. B. (2007). Living-learning programs and firstgeneration college students' academic and social transition to college. Research in Higher Education, 48(4), 403-434. http://doi.org/10.1007/s11162-006-9031-6

[45] Ishitani, T. T. (2003). A longitudinal approach to assessing attrition behavior among first-generation students: Time-Varying Effects of Pre-College Characteristics. Research in Higher Education, 44(4), 433449. http://doi.org/10.1023/A:1024284932709

[46] Jehangir, R. R. (2009). Cultivating voice: First-generation students seek full academic citizenship in multicultural learning communities. Innovative Higher Education, 34(1), 33-49. http://doi.org/10.1007 /s10755-008-9089-5 
[47] Jenkins, S. R., Belanger, A., Connally, M. L., Boals, A., \& Durõn, K. M. (2013). First-generation undergraduate students' social support, depression, and life satisfaction. Journal of College Counseling, 16(2), 129-142. http://doi.org/10.1002/j.2161-1882.2013.00032.x

[48] Jury, M., Smeding, A., Court, M., \& Darnon, C. (2015). When first-generation students succeed at university: On the link between social class, academic performance, and performance-avoidance goals. Contemporary Educational Psychology, 41, 25-36. http://doi.org/10.1016/j.cedpsych.2014.11.001

[49] Jury, M., Smeding, A., \& Darnon, C. (2015). First-generation studentsâ€TM underperformance at university: the impact of the function of selection. Frontiers in Psychology, 6(MAY), 710. http://doi.org/10.3389/ fpsyg.2015.00710

[50] Kahle, L., \& Hansen, K. H. (2009). Work in progress - globalization and business innovation: How do we best prepare millennial-generation engineering students for complex challenges? In 2009 39th IEEE Frontiers in Education Conference (pp. 1-2). IEEE. http://doi.org/10.1109/FIE.2009.5350664

[51] Keller, U., \& Tillman, K. H. (2008). Post-secondary Educational Attainment of Immigrant and Native Youth. Social Forces, 87(1), 121-152. http://doi.org/10.1353/sof.0.0104

[52] Kim, Y. K., \& Sax, L. J. (2009). Student-faculty interaction in research universities: Differences by student gender, race, social class, and first-generation status. Research in Higher Education, 50(5), 437-459. http://doi.org/10.1007/s11162-009-9127-x

[53] Kirshner, B., Saldivar, M. G., \& Tracy, R. (2011). How first-generation students learn to navigate education systems: A case study of First Graduate. New Directions for Youth Development, 2011(S1), 107-122. http://doi.org/10.1002/yd.421

[54] Knight, Y. (2009). Talkin' 'bout my generation: a brief introduction to generational theory. Planet, 1835(21), 13-15. http://doi.org/10.11120/plan.2009.00210013

[55] Kouyoumdjian, C., Guzman, B. L., Garcia, N. M., \& Talavera-Bustillos, V. (2015). A Community Cultural Wealth Examination of Sources of Support and Challenges Among Latino First- and SecondGeneration College Students at a Hispanic Serving Institution. Journal of Hispanic Higher Education, 116. http://doi.org/10.1177/1538192715619995

[56] Lam, P. C., Srivatsan, T., Doverspike, D., Vesalo, J., \& Mawasha, P. R. (2005). Description of a ten year study of the pre-engineering program for under-represented, low income and/or first generation college students at the university of akron. Journal of STEM Education, 6(3 \& 4), 14-20. http://doi.org/10.1109/ FIE.2004.1408599

[57] Lang, D. W. (2009). Articulation, transfer, and student choice in a binary post-secondary system. Higher Education, 57(3), 355-371. http://doi.org/10.1007/s10734-008-9151-3

[58] Lub, X. D., Bal, P. M., Blomme, R. J., \& Schalk, R. (2016). One job, one deal...or not: do generations respond differently to psychological contract fulfillment? The International Journal of Human Resource Management, 27(6), 653-680. http://doi.org/10.1080/09585192.2015.1035304

[59] M.S.Thirumalai. (2014). Soft Skills for First Generation Students, Teachers and Professionals. Language in India, 14(7), 569-571. Retrieved from http://www.languageinindia.com/feb2011/mobilegujjar.html

[60] Madsen, L. D., \& Tessema, G. X. (2009). The next generation: Education and broadening participation in science and engineering. Journal of Electroceramics, 22(1-3), 8-12. http://doi.org/10.1007/s10832-008-9417-2

[61] Majer, J. M. (2009). Self-efficacy and academic success among ethnically diverse first-generation community college students. Journal of Diversity in Higher Education, 2(4), 243-250. http://doi.org/ 10.1037/a0017852

[62] Martin, J. P. (2015). The invisible hand of social capital: Narratives of first generation college students in engineering. International Journal of Engineering Education, 31(5), 1170-1181. Retrieved from http://www.scopus.com/inward/record.url?eid=2-s2.0-84940434769\&partnerID=tZOtx3y1

[63] Martin, J. P., Miller, M. K., \& Simmons, D. R. (2014). Exploring the theoretical social capital "deficit" of first generation college students: Implications for engineering education. International Journal of Engineering Education, 30(4), 822-836. Retrieved from http://www.scopus.com/inward/record.url?eid=2s2.0-84906318325\&partnerID=tZOtx3y1

[64] Martin Lohfink, M., \& Paulsen, M. B. (2005). Comparing the Determinants of Persistence for FirstGeneration and Continuing-Generation Students. Journal of College Student Development, 46(4), 409428. http://doi.org/10.1353/csd.2005.0040

[65] Martin-Garcia, T., \& Baizan, P. (2006). The impact of the type of education and of educational enrolment on first births. European Sociological Review, 22(3), 259-275. http://doi.org/10.1093/esr/jci056

[66] Mawasha, P. R. (2008). A Pre-Engineering Program for the Under-Represented, Low-Income and / or First Generation College Students to Pursue Higher Education, 9(3), 5-15.

[67] McGonagle, A. K., Freake, H. C., Zinn, S., Bauerle, T., Winston, J., Lewicki, G., ... Philion, M. (2014). Evaluation of STRONG-CT: A Program Supporting Minority and First-Generation U.S. Science Students. Journal of STEM Education: Innovations \& Research, 15(1), 52-61. 
[68] McKay, V. C., \& Estrella, J. (2008). First-generation student success: The role of faculty interaction in service learning courses. Communication Education, 57(3), 356-372. http://doi.org/10.1080/03634520801966123

[69] Meurs, D., Puhani, P. A., \& Von Haaren-Giebel, F. (2016). Number of siblings and educational choices of immigrant children: evidence from first- and second-generation immigrants. Review of Economics of the Household. http://doi.org/10.1007/s11150-015-9320-y

[70] Moschetti, R. V., \& Hudley, C. (2015). Social Capital and Academic Motivation Among First-Generation Community College Students. Community College Journal of Research and Practice, 39(3), $235-251$. http://doi.org/10.1080/10668926.2013.819304

[71] Naafs, S., \& White, B. (2012). Intermediate Generations: Reflections on Indonesian Youth Studies. The Asia Pacific Journal of Anthropology, 13(1), 3-20. http://doi.org/10.1080/14442213.2012.645796

[72] Nuñez, A. (2005). Negotiating Ties: A Qualitative Study of First-Generation Female Students ' Transitions to College. Journal of The First-Year Experience, 17(2), 87-118.

[73] Nuñez, A.-M. (2011). Counterspaces and Connections in College Transitions: First-Generation Latino Students' Perspectives on Chicano Studies. Journal of College Student Development, 52(6), 639-655. http://doi.org/10.1353/csd.2011.0077

[74] O’Shea, S. (2014). Transitions and turning points: exploring how first-in-family female students story their transition to university and student identity formation. International Journal of Qualitative Studies in Education, 27(2), 135-158. http://doi.org/10.1080/09518398.2013.771226

[75] Orbe, M. P. (2004). Negotiating multiple identities within multiple frames: An analysis of first-generation college students. Communication Education, 53(2), 131-149. http://doi.org/10.10/03634520410001682401

[76] Padgett, R. D., Johnson, M. P., \& Pascarella, E. T. (2012). FIrst-generation undergraduate students and the impacts of the first year of college: Additional evidence. Journal of College Student Development, 53(2), 243-266. http://doi.org/10.1353/csd.2012.0032

[77] Pandey, A. (2015). Educational Achievements of First and Subsequent Generation Learners in East Delhi/Ncr Region in India - A Comparative Study. Asian Development Policy Review, 3(2), 20-28. http://doi.org/10.18488/journal.107/2015.3.2/107.2.20.28

[78] Paul Grayson, J. (2011). Cultural capital and academic achievement of first generation domestic and international students in Canadian universities. British Educational Research Journal, 37(4), 605-630. http://doi.org/10.1080/01411926.2010.487932

[79] Peguero, A. A., Shekarkhar, Z., Popp, A. M., \& Koo, D. J. (2015). Punishing the Children of Immigrants: Race, Ethnicity, Generational Status, Student Misbehavior, and School Discipline. Journal of Immigrant \& Refugee Studies, 13(2), 200-220. http://doi.org/10.1080/15562948.2014.951136

[80] Peterson, C. (2016). Non-Cognitive Contributors to Student Success Among First Generation Students, (JANUARY2015),0-31. http://doi.org/10.13140/RG.2.1.3264.0084

[81] Pfirman, A. L., Miller, M. K., Alvarez, G. A. S., \& Martin, J. P. (2014). First generation college students' access to engineering social capital: Towards developing a richer understanding of important alters. 2014 IEEE Frontiers in Education Conference (FIE) Proceedings, 2015-Febru(February), 1-7. http://doi.org/10.1109/FIE.2014.7044268

[82] Pham, C., \& Keenan, T. (2011). Counseling and college matriculation : Does the availability of counseling affect college-going decisions among highly qualified first-generation college-bound high school graduates? Journal of Applied Economics and Business Research, 1(February), 12-24.

[83] Pike, G. R., \& Kuh, G. D. (2005). A typology of Student Engagement for American colleges and Universities . Research in Higher Education, 46(2), 185-209. http://doi.org/10.1007/s

[84] Pinzaru, F., \& Mitan, A. (2013). Generation Y Students : Using Facebook for Communicating with University Sta ff and Professors. Management Dynamics in the Knowledge Economy, 1(2), 221-239.

[85] Pontes, M. C. F., \& Pontes, N. M. H. (2012). Distance Education Enrollment is Associated with Greater Academic Progress Among First Generation Low-Income Undergraduate Students in the US in 2008. Online Journal of Distance Learning Administration,15(1),1.Retrievedfrom https://acces.bibl.ulaval .ca/login?url=https://search.ebscohost.com/login.aspx?direct=true\&db=eue\&AN=73801299\&lang=fr\&site =ehost-live

[86] Pottie, K., Dahal, G., Georgiades, K., Premji, K., \& Hassan, G. (2014). Do First Generation Immigrant Adolescents Face Higher Rates of Bullying, Violence and Suicidal Behaviours Than Do Third Generation and Native Born? Journal of Immigrant and Minority Health, 17(5), 1557-1566. http://doi.org/10.1007/s10903-014-0108-6

[87] Próspero, M., \& Vohra-Gupta, S. (2007). First Generation College Students: Motivation, Integration, and Academic Achievement. Community College Journal of Research and Practice, 31(12), 963-975. http://doi.org/10.1080/10668920600902051 
[88] Rahim, A. H. A., \& Azman, N. (2010). Educational aspirations among first-generation students and their parental influence towards pursuing tertiary education. Procedia - Social and Behavioral Sciences, 7(C), 414-418. http://doi.org/10.1016/j.sbspro.2010.10.056

[89] Ramos-Sánchez, L., \& Nichols, L. (2007). Self-efficacy of first-generation and non-first-generation college students: The relationship with academic performance and college adjustment. Journal of College Counseling, 10(1), 6-18. http://doi.org/10.1002/j.2161-1882.2007.tb00002.x

[90] Reid, M. J., \& Iii, J. L. M. (2008). College Readiness and Postsecondary Education Urban College Students. Urban Education, 43(2), 240-261. Retrieved from http://uex.sagepub.com

[91] Rood, R. E. (2009). Driven to Achieve: First-Generation Students' Narrated Experience at a Private Christian College. Christian Higher Education, 8(3), 225-254. http://doi.org/10.1080/15363750802708494

[92] Schuetz, P. (2014). Unit Completion Ratio: Assessing Influences of Campus on Community College Student Success. Community College Journal of Research and Practice, 38(7), 612-624. http://doi.org/10.1080/10668926.2012.676502

[93] Schulte, D. P., Slate, J. R., \& Onwuegbuzie, A. J. (2011). Hispanic college students' views of effective middle-school teachers: A multi-stage mixed analysis. Learning Environments Research, 14(2), 135-153. http://doi.org/10.1007/s10984-011-9088-9

[94] Shields, N. (2002). Anticipatory Socialization, Adjustment to University Life, and Perceived Stress: Generational and Sibling Effects. Social Psychology of Education : AnInternationalJournal,5(4),365-392. http://doi.org/http://dx.doi.org/10.1023/A:1020929822361

[95] Somers, P., Woodhouse, S. R., \& Cofer, J. E. (2004). Pushing the Boulder Uphill: The Persistence of FirstGeneration College Students. Journal of Student Affairs Research and Practice, 41(3), 811-828. http://doi.org/10.2202/1949-6605.1353

[96] Soria, K. M., \& Stebleton, M. J. (2012). First-generation students' academic engagement and retention. Teaching in Higher Education, 17(March 2015), 1-13. http://doi.org/10.1080/13562517.2012.666735

[97] Southgate, E., Douglas, H., Scevak, J., Macqueen, S., \& Rubin, M. (2014). The academic outcomes of first-in-family in an Australian university: An exploratory study. International Studies in Widening Participation, 1(2), 31-45.

[98] Spiegler, T., \& Bednarek, A. (2013). First-generation students: what we ask, what we know and what it means: an international review of the state of research. International Studies in Sociology of Education, 23(4), 318-337. http://doi.org/10.1080/09620214.2013.815441

[99] Stebleton, M. J., Soria, K. M., Huesman, R. L., \& Torres, V. (2014). Recent Immigrant Students at Research Universities: The Relationship Between Campus Climate and Sense of Belonging. Journal of College Student Development, 55(2), 196-202. http://doi.org/10.1353/csd.2014.0019

[100] Stephens, N. M., Fryberg, S. a., Markus, H. R., Johnson, C. S., \& Covarrubias, R. (2012). Unseen disadvantage: How American universities' focus on independence undermines the academic performance of first-generation college students. Journal of Personality and Social Psychology, 102(6), 1178-1197. http://doi.org/10.1037/a0027143

[101] Stephens, N. M., Townsend, S. S. M., Markus, H. R., \& Phillips, L. T. (2012). A cultural mismatch: Independent cultural norms produce greater increases in cortisol and more negative emotions among firstgeneration college students. Journal of Experimental Social Psychology, 48(6), 1389-1393. http://doi.org/10.1016/j.jesp.2012.07.008

[102] Stieha, V. (2010). Expectations and experiences: the voice of a first-generation first-year college student and the question of student persistence. International Journal of Qualitative Studies in Education, 23(2), 237-249. http://doi.org/10.1080/09518390903362342

[103] Stuber, J. M. (2011). Integrated, marginal, and resilient: race, class, and the diverse experiences of white first-generation college students. International Journal of Qualitative Studies in Education, 24(1), 117136. http://doi.org/10.1080/09518391003641916

[104] Szelenyi, K. (2013). The Meaning of Money in the Socialization of Science and Engineering Doctoral Students: Nurturing the Next Generation of Academic Capitalists? Journal of Higher Education, 84(2), 266-294. http://doi.org/10.1353/jhe.2013.0008

[105] Tate, K. a., Fouad, N. a., Marks, L. R., Young, G., Guzman, E., \& Williams, E. G. (2015). Underrepresented First-Generation, Low-Income College Students' Pursuit of a Graduate Education: Investigating the Influence of Self-Efficacy, Coping Efficacy, and Family Influence. Journal of Career Assessment, 23(3), 427-441. http://doi.org/10.1177/1069072714547498

[106] Théroux, P. J. (2009). Work in progress - Creating cross-generational Co-learning opportunities through inquiry-based curricula. In Proceedings - Frontiers in Education Conference, FIE (pp. 1-2). http://doi.org/10.1109/FIE.2009.5350824 
[107] Trammell, B., \& Aldrich, R. (2016). Undergraduate Students' Perspectives of Essential Instructor Qualities. Journal of the Scholarship of Teaching and Learning, 16(1), 15. http://doi.org/10.14434/josotl .v16i1.19178

[108] Trenor, J. M. (2009). Phenomenological Inquiry of the Major Choice Processes of an Overlooked Demographic.Pdf. In Proceedings of The Research in Engineering Education Symposium (pp. 1-6).

[109] Trenor, J. M., \& Grant, D. S. (2009). Work in progress - A research-based tool kit for communicating unique messages about engineerings first generation college students. In Proceedings - Frontiers in Education Conference, FIE (pp. 5-6). http://doi.org/10.1109/FIE.2009.5350856

[110] Trevino, N. N., \& DeFreitas, S. C. (2014). The relationship between intrinsic motivation and academic achievement for first generation Latino college students. Social Psychology of Education, 17(2), 293-306. http://doi.org/10.1007/s11218-013-9245-3

[111] Twenge, J. M., Campbell, W. K., \& Gentile, B. (2012). Generational Increases in Agentic Selfevaluations among American College Students, 1966-2009. Self and Identity, 11(4), 409-427. http://doi.org/10.1080/15298868.2011.576820

[112] Vega, D., \& Moore, J. L. I. (2012). African American and Latino first-generation students: Implications for teachers, school counselors, university officials, parents, and students. In Research studies in higher education: Educating multicultural students (pp. 3-25).

[113] Virnoche, M., \& Eschenbach, E. A. (2010). Race, gender and first generation status in computing science, engineering and math persistence. In Proceedings - Frontiers in Education Conference, FIE (pp. 1-6). http://doi.org/10.1109/FIE.2010.5673137

[114] Wang, T. R. (2012). Understanding the Memorable Messages First-Generation College Students Receive from On-Campus Mentors. Communication Education, 61(4), 335-357. http://doi.org/10.1080/03634523.2012.691978

[115] Watt, K. M., Johnston, D., Huerta, J., Mendiola, I. D., \& Alkan, E. (2008). Retention of First-Generation College-Going Seniors in the College Preparatory Program AVID. American Secondary Education, 37(1), 17-40. Retrieved from http://sfx.scholarsportal.info.librweb.laurentian.ca/laurentian?url_ver=Z39.882004\&rft_val_fmt=info:ofi/fmt:kev:mtx:journal\&genre=article\&sid=ProQ:ProQ\%3Aericshell\&atitle=Ret ention+of+First-Generation+College-Going+Seniors+in+the+College+Preparatory+Pr

[116] Wentworth, P. A., \& Peterson, B. E. (2001). Crossing the Line: Case Studies of Identity Development in First-Generation College Women. Journal of Adult Development, 8(1), 9-21. http://doi.org/10.1023/A:1026493620218

[117] Wildhagen, T. (2015). Not Your Typical Student: The Social Construction of the First-Generation College Student. Qualitative Sociology, 38(3), 285-303. http://doi.org/10.1007/s11133-015-9308-1

[118] Wilkins, A. C. (2014). Race, Age, and Identity Transformations in the Transition from High School to College for Black and First-generation White Men. Sociology of Education, 87(3), 171-187. http://doi.org/10.1177/0038040714537901

[119] Williams, P. E., \& Hellman, C. M. (2004). Differences in self regulation for online learning between first and second generation college students. Research in Higher Education, 45(1), 71-82. http://doi.org/10.1023/B

[120] Williams, S. M., \& Ferrari, J. R. (2015). Identification among first generation citizen students and first generation college students : An Exploration of School sense of Community. Journal of Community Psychology, 43(3), 377-387. http://doi.org/10.1002/jcop.21685

[121] Wohn, D. Y., Ellison, N. B., Khan, M. L., Fewins-Bliss, R., \& Gray, R. (2013). The role of social media in shaping first-generation high school students' college aspirations: A social capital lens. Computers and Education, 63(February), 424-436. http://doi.org/10.1016/j.compedu.2013.01.004

Citation: Dr. Vijayalakshmi N.S, Dr. A.H Sequeira. "Campus Adaptations among First Generation and Non First-Generation Students" International Journal of Research in Sociology and Anthropology (IJRSA), vol 4, no. 2, 2018, pp. 17-30. doi:http://dx.doi.org/10.20431/2454-8677.0402003.

Copyright: (C) 2018 Authors. This is an open-access article distributed under the terms of the Creative Commons Attribution License, which permits unrestricted use, distribution, and reproduction in any medium, provided the original author and source are credited. 